\title{
VIOLENCE AGAINST INFANTS AND CHILDREN - PRACTICAL IMPLICATIONS REGARDING PREVENTION ISSUES
}

\author{
Salvatore Giacomuzzi \\ Doctor of Medical Sciences (DDr.), Department of Psychiatry and Psychotherapy, Vienna, Austria \\ E-mail: salvatore.giacomuzzi@sfu.ac.at, https://orcid.org/0000-0002-4218-1685 \\ Klaus Garber \\ E-mail:klaus.garber@sfu.ac.at, https://orcid.org/0000-0002-0958-0641 \\ Assoz. Prof., Dr., Department Psychologie, Sigmund Freud Privat Universitat, Wien, Austria \\ Marcus Ertl \\ Department of Psychiatry, University of Innsbruck, Innsbruck, Austria \\ Natalia Barinova \\ V.N. Karazin Kharkiv National University \\ Pl. Svobody 6, Kharkov, 61022, Ukraine \\ E-mail: barinova.n2310@gmail.com, https://orcid.org/0000-0001-5103-0611 \\ Alexander Kocharian \\ V.N. Karazin Kharkiv National University \\ m. Svobody 6, Kharkov, 61022, Ukraine \\ E-mail: kocharian55@gmail.com, https://orcid.org/0000-0001-8998-3370
}

\begin{abstract}
The article presents an overview of the problems of child violence, a wide range of its variants-physical, sexual and psychological violence, etc. It is shown that child violence has the quality of transgeneration, in one form or another, is reproduced in the next generations. The experience of violence is also a negative predictor of violent behavior that will manifest itself in the upbringing of their own children. Indicators of the epidemiology of violence are presented. The data vary greatly, for example, the prevalence of sexual violence ranges from $3 \%$ to $36 \%$. Sexual violence mainly affects children between the ages of 6 and 13 . Children under the age of 4 are most likely to suffer from physical and psychological abuse. Up to a third of victims of sexual violence may show appropriate behavior towards their own or other children. An overview of the factors that predispose / retard the formation of child violence is presented. These are factors such as age, gender, ethnic origin, disability, and social status of the parents. Prevention work should be based on a multi-level concept (multiple participants or institutions are involved). Appropriate measures to prevent violence should not (cannot) only target children / young people, but should also affect, in particular, parents and schools.
\end{abstract}

KEYWORDS: sexual, physical and psychological abuse of children, epidemiology and prevention of child violence.

\section{Preliminary considerations}

Many years ago, two parents were sentenced to several years/life sentences, because the father in particular abused his own child so severely that the infant died as a result. The mother of the child was mainly acting in doing nothing against the maltreatment of her own child. The mother was released from prison after a few years. In the course of serving her sentence, the mother consecrated therapeutic measures/offers. She settled down again, met a new life partner (who soon left her) and had a child again. For me, the first author, I was faced with the professional question of whether this mother would again create circumstances, in order that the new-born infant would also have to fear a threat against a child's well-being. However, I was at that time in particular interested in the special circumstances which could lead to such a behaviour.

\section{Introduction}

Finkelhor (1998) already 20 years ago compared international studies on the epidemiology of sexual abuse. He found sexual abuse experiences in at least $7 \%$ of women and $3 \%$ of men, with data from up to $36 \%$ of women (Austria) and $29 \%$ of men (South Africa) (Finkelhor, 1998). However, the number of unreported cases is much higher.

In 2018 more than 8500 children in Germany became victims of dangerous or severe injuries. According to the Federal Criminal Statistics Austria (2011) crimes were reported in the age group from 0 to 10 years: 12 dead infants, 186 cases of torture or neglect, 2.175 cases of injuries and 699 cases of sexual abuse. 
But not all children are equally at risk. The problems of the individual case depend on age, gender, ethnic origin, disability and social status.

In the area of sexual abuse, the estimates are about 5-11 times higher. Children up to the age of 4 years are most frequently affected by physical and psychological abuse, and in the case of sexual abuse mainly children from 6 to 13 years.

The frequency of deaths due to consequences of violence is calculated at $0.1-3.7 / 100.000$. Children under one year of age are exposed to up to six times the risk. Children up to four years are still at twice the risk. Children who parents are shaken are particularly at risk. The lethal cases here amount to $25 \%$ (WHO 2003, ).

The most important risk factor is the lived violence in the family.

Current findings suggest that physical neglect is directly linked to economic stressors, while low parental education is consequential for both physical and supervisory neglect. Both types of neglect also are strongly associated with risk of other maltreatment and most other forms of victimization. Physical neglect is particularly strongly related to sexual abuse and witnessing sibling abuse, while supervisory neglect is most strongly related to risk for sexual victimization by a nonfamily adult. Although neglect is significantly associated with trauma symptoms, poly-victims had, by far, the highest levels of trauma symptoms (Turner, 2019).

\section{Experiences of violence in childhood and youth}

Estimates suggest that $15 \%$ of children in the United Kingdom have been exposed to at least one form of domestic violence(DV) during their childhood, with more than 3\% having witnessed an incident during the past year.

This exposure increases the risk of children suffering both short-term and long-term impacts, including effects on their behaviour, social development, physical and mental health, educational attainment and quality of life. In addition, children living in environments where there is DV are at higher risk of maltreatment.

Adult relatives and friends of the family often observe the experiences of children in situations of $\mathrm{DV}$, and have the potential to shed light in a way that children and survivors may struggle to articulate, or be reluctant to acknowledge or disclose. Such accounts are largely absent from existing research, and yet bring a perspective which can broaden our understanding of the impact that DV has on children. This exposure to violence increases the risk that children are at risk of both short-term and long-term effects, including effects on their behaviour, social development, physical and mental health, educational attainment and quality of life. In addition, children living in these environments are at higher risk of abuse (Gregory, 2019).

Within the framework of the transgenerational transmission of one's own experiences of attachment, one's own experiences of violence are also a negative predictor of violent behaviour practised by oneself in the upbringing of one's own children. Not to be neglected is the fact that up to one third (33\%) of the victims of sexual abuse experiences can show corresponding behaviour towards their own or other children (Giacomuzzi, Velasquez-Montiell, Scherer, Ertl, Garber, 2017a).

The figures vary only slightly in time and in regard to German-speaking areas. In particular, the violence between young people, which can be a determining factor in their further development, must not be neglected. In a representative German study, almost one in five young people (18.9\%) stated that they had been victims of violence in the last 12 months. In relation to the entire lifetime to date, twice as many young people (38.9\%) have suffered a violent crime at least once (Gewalterfahrungen von Kindern und Jugendlichen, 2007). In $3.1 \%$ of all violent crimes the injury was so serious that inpatient treatment with a longer stay in hospital became necessary. A fifth $(20 \%)$ of all assaults a weapon was involved (e.g. measuring stick, baton, and brass knuckles).

Thus, in the study, two out of five adolescents were exposed to violence by family members during childhood. The most common form of parental assault is light corporal punishment (slaps in the face or hard gripping). As the study shows, male adolescents have a significantly higher risk of victimisation than female adolescents (with the exception of sexual violence). Up to $20.8 \%$ of the students in the study cited were also severely chastised (frequent experience of e.g. slaps in the face and rough grabbing) or even maltreated (fist slapping, beating).

In the literature, sexual abuse is often referred to as a dysfunctional family structure as a risk factor for the pathogenic development of children and adolescents. Various studies (e.g. Joraschky \& Petrowski, 2016) have found, for example, that a lack 
of parental warmth during childhood is confirmed as a risk factor for the later development of depression (Bender, 2016).

In a recent study (Giacomuzzi, VelasquezMontiell, Scherer, Ertl, Garber, 2017b), for example, it was found that parents of students who had experienced sexual abuse in their childhood were significantly more likely to have abused alcohol or drugs or suffered from a mental disorder than students who had not experienced sexual abuse in their childhood (Giacomuzzi, Scherer, VelasquezMontiell, Ertl, Garber, 2017b).

As a summary it can be stressed out that violence begins to a considerable extent in early childhood, continues within the family and between young people during adolescence and has a long-term negative influence on their experience and behaviour.

\section{Violence in partner relationships and in different ethnic groups}

Intimate partner violence is also an issue of public health and especially the social and economic circumstances in which women/mothers live. Punjab, for example, is a male-dominated society in which partner violence is generally accepted as a cultural norm and considered normal behaviour within a marriage. It results from the attitude that partner violence is a private matter and usually a justified reaction to misconduct of the woman (Nadeem, 2019). In a large-scale Multi-Indicator Cluster Survey (MICS) in Punjab province, the effects of the cultural norm on the attitude of the wife were investigated. The results suggest that wife beating is accepted as a community norm. The level of education of women plays the most important ole in rejecting the wife-beating norm, as an increase in level of education is associated with an increase in the probability of rejecting the wife-beating. So, the current study suggests that there is a dire need to increase the female education level to overcome this issue.

The risk of becoming a victim of intra-family violence varies, as we've seen already above according to ethnicity or cultural background: while $17.0 \%$ of German youths, for example, have suffered serious forms of parental violence in childhood, the figure is $30.7 \%$ for Italian youths, $29.8 \%$ for Turkish youths, $27.9 \%$ for (ex-)Yugoslavian youths and $25.4 \%$ for Russian youths. From that numbers it is very clear that the risk of becoming a victim of intra- family violence varies, according to ethnicity and cultural background (Giacomuzzi, VelasquezMontiel, 2017c).

Violence by intimate partners is one of the most frequently reported crimes. Black women, for example, reported violence by intimate partners to the police twice as often as white women. From an ethnic point of view, police reports of violence by black women increased significantly with increasing age between 18 and $<35$ years. Latin American mothers with less than a high school education were the least likely to report to the police. Moreover, a culture of silence and discrimination, influences of socioeconomic status and social desirability often prevails (Holliday, 2019).

Despite compromising women's health and safety, intimate partner violence (IPV) is among the most underreported crimes, and our understanding of factors that drive police reporting by race/ethnicity is underdeveloped. Intimate partner violence during pregnancy is a risk factor for unwanted pregnancies and birth outcomes. As shown there is a connection between partner violence before and during pregnancy and participation in supplementary or supporting programmes for low-income families.

The purpose of a study by (Holliday, 2019) was to examine racial/ethnic differences in selfreporting IPV to police. Race/ethnicity-stratified models identified predictors of reporting IPV to police among recent, female survivors $(n=898)$ in the National Crime Victimization Survey (NCVS; 2011-15). Focus groups $(\mathrm{n}=3)$ with recent survivors $(\mathrm{n}=19)$ in Baltimore, MD (2018), contextualized results. Black women in the NCVS were twice as likely to report IPV to police relative to White. In race/ethnicity-stratified models, police reporting significantly increased with increasing age between 18 and $<35$ years for Black women, and with IPV-related injury for Black and Hispanic women. Hispanics with less than a high school education were least likely to report. Focus groups explained racial/ethnic influences on reporting including a culture of silence and discrimination, socioeconomic status, and social desirability. The authors identified influences on reporting IPV to police that vary by race/ethnicity using national data in context to an urban environment.

Let us therefore further note that violence is also influenced by ethnicity, social status and education. 


\section{Practical Implications}

In a 5-year study on the prevalence of physical violence against children and adolescents in Recife, Brazil, 9783 incidents were evaluated in which mainly male children were the victims $(\mathrm{n}=5447,55.7 \%)$. The average age of the victims was 13.9 years, the most frequent perpetrators were acquaintances of the victims $(n=2538$, $25.9 \%$ ). Facial injuries in particular were the most common features of violence, affecting just over a fifth of the entire sample $(n=3673,20.1 \%)$ (Masho, 2019).

Early intervention violence problems can be dealt with more effectively the younger the persons to whom prevention efforts are directed. In the first years of life, however, children are already at risk of being neglected by their parents or becoming victims of parental violence due to difficult family circumstances (poverty, poor housing conditions, social exclusion, etc.) (Giacomuzzi, Velasquez-Montiel, 2017d). For example, video analyses should also be mentioned here, which allow parents to see their own behaviour and which can be used to identify specific resources and eliminate deficits.

In infancy and early childhood, the family has the greatest influence on personal development, and even at primary school age, the family continues to play an important role, although the weight of peers and school is increasing.

In adolescence, orientation towards the school environment, the peers and the residential area (e.g. leisure and consumer activities) predominate.

The involvement of young people can also be crucial, because their commitment and the considerable influence of their peers contribute significantly to the acceptance and success of prevention measures among young people.

In Austria, about 370,000 children are currently affected by poverty and exclusion (Tag der Kinderrechte Österreich; 2019). In early childhood a close cooperation between different stake holders is essential to prevent violence against children and infants. In summary, prevention work must be based on a multi-level concept (several actors or institutions participate). Appropriate measures to prevent violence must not/cannot only be directed at children/young people, but must also involve parents and the school in particular (Giacomuzzi, VelasquezMontiel, 2017e).

\section{REFERENCES}

Bender/Lösel, Risikofaktoren, Schutzfaktoren und Resilienz bei Miss-handlung und Vernachlässigung. (2016). In: Egle/Joraschky/Lampe/SeiffgeKrenke/Cierpka, (Hrsg.). Sexueller Missbrauch, Misshandlung, Vernach-lässigung. Erkennung, Therapie und Prävention der Folgen früher Stresserfahrungen, 77-103. 4. überarbeitete und erweiterte Auflage, Stuttgart: Schattauer.

Finkelhor, D. (1998). Zur internationalen Epidemiologie von sexuellem Missbrauch an Kindern. In: G. Amann \& R. Wipplinger (Hrsg.), Sexueller Missbrauch. 72-85. Tübingen: dgvt.

Holliday C.N., Kahn G., Thorpe R.J. Jr.4, Shah R., Hameeduddin Z., Decker M.R. (2019). Racial/Ethnic Disparities in Police Reporting for Partner Violence in the National Crime Victimization Survey and Survivor-Led Interpretation. J Racial Ethn Health Disparities. $\quad 2019 \quad$ Dec 11. https://doi.org/10.1007/s40615-019-00675-9.

Gewalterfahrungen von Kindern und Jugendlichen. (2007). Kriminologi-Sches Forschungsinstitut Niedersachsen E.V.

Giacomuzzi S., Velasquez-Montiell, B., Scherer, Ertl, M., Garber, K. (2017a). Sexuelle Übergriffe in Kindheit und Jugend: Eine aktuelle, österreichische Untersuchung. Richterzeitung. 1; 31-35

Giacomuzzi S., Scherer B., Velasquez-Montiell S., Ertl M., Garber K., (2017b). Aktuelle Untersuchungsdaten zum sexuellen Missbrauch in Österreich unter Berücksichtigung der Familienumstände und den Auswirkungen auf die Betroffenen im frühen Erwachsenenalter. Ifamz. 1; 63-72.

Giacomuzzi, S. Velasquez-Montiel, S. (2017c): Kinder und Jugendliche, die kriminelle Handlungen erfahren haben. In: Freiberger, A.M; Mandl, P; Schwarzinger, F. (Hrsg): Praxishandbuch Kinderund Jugendschutz, Kapitel 8.5.9.

Giacomuzzi, S. Velasquez-Montiel, S. (2017d): Kinder und Jugendliche, die kriminelle Handlungen erfahren haben. In: Freiberger, A.M; Mandl, P; Schwarzinger, F. (Hrsg): Praxishandbuch Kinderund Jugendschutz, Kapitel 8.5.9.

Giacomuzzi, S. Velasquez-Montiel, S. (2017e): Kinder und Jugendliche, die kriminelle Handlungen erfahren haben. In: Freiberger, A.M.; Mandl, P; Schwarzinger, F. (Hrsg): Praxishandbuch Kinderund Jugendschutz, Kapitel 8.5.9.

Gregory A., Arai L., MacMillan H.L., Howarth E., Shaw, A. (2019). Children's experiences and needs in situations of domestic violence: A secondary analysis of qualitative data from adult friends and family members of female survivors. Health Soc Care

Community. https://doi.org/10.1111/hsc.12893. 
Masho S.W., Rozario S.S., Ferrance J.L. (2019). Intimate Partner Violence Around the Time of Pregnancy and Utilization of WIC Services. Matern Child Health J. 23(12) 1648-1657. https://doi.org/10.1007/s10995019-02811-7.

Nadeem M, Malik MI. The Role of Social Norm in Acceptability Attitude of Women Toward Intimate Partner Violence in Punjab, Pakistan. J Interpers
Violence. 2019 Nov 29:886260519889942. https://doi.org/10.1177/0886260519889942.

Tag der Kinderrechte Österreich; (2019).

Turner HA, Vanderminden J, Finkelhor D, Hamby S.

(2019). Child Neglect and the Broader Context of Child Victimization. Child Maltreat. 24(3). 265-274. https://doi.org/10.1177/1077559518825312.

WHO (2003). US Dep Health \& Sciences 2002

\section{НАСИЛЛЯ ПРОТИ НЕМОВЛЯТ І ДІТЕЙ - ПРАКТИЧНІ НАСЛІДКИ,} ЩО ВІДПОВІДАЮТЬ ПРОБЛЕМІ ПРОФІЛАКТИКИ

Сальваторе Джакомуцці Доктор медичних наук, доктор психологічних наук, кафедра психіатрї та психотерапї̈, Вiдень, Австрія

Клаус Гарбер

Доцент, доктор, факультет психології, Університет Зигмунда Фрейда, Відень, Австрія

М. Ертл

Кафедра психіатрії, Університет Інсбрука, Інсбрук, Австрія

Наталія Барінова

Харківський начіональний університет імені В.Н. Каразіна, Харків, Украӥна

Олександр Кочарян

Харківський наиіональний університет імені В.Н. Каразіна, Харків, Украӥна У статті представлений огляд проблем дитячого насильства, широкий спектр його варіантів - фізичного, сексуального $\mathrm{i}$ психологічного насильства і т.п. Показано, що дитяче насильство володіє якістю трансгенерації, в тій чи іншій формі відтворюється в наступних поколіннях. Досвід насильства також є негативним предиктором насильницької поведінки, яка проявиться у вихованні власних дітей. Представлені показники епідеміології насильства. Дані дуже коливаються, наприклад, поширеність сексуального насильства коливається від 3\% до 36\%. Від сексуального насильства в основному страждають діти у віці від 6 до 13 років. Діти віком до 4 років найчастіше страждають від фізичного та психологічного насильства. До третини жертв сексуального насильства можуть проявляти відповідну поведінку по відношенню до своїх або інших дітей. Представлений огляд факторів, які предиспонують / ретардують формування дитячого насильства. Це такі фактори, як вік, стать, етнічне походження, наявність інвалідності та соціальний статус батьків. Профілактична робота повинна грунтуватися на багаторівневій концепції (беруть участь кілька учасників або установ). Відповідні заходи щодо запобігання насильству не повинні (не можуть) бути спрямовані тільки на дітей / молодих людей, але повинні також зачіпати, зокрема, батьків і школу. КЛЮЧОВІ СЛОВА: сексуальне, фізичне та психологічне насильство над дітьми, епідеміологія та профілактика дитячого насильства.

НАСИЛИЕ ПРОТИВ МЛАДЕНЦЕВ И ДЕТЕЙ - ПРАКТИЧЕСКИЕ ПОСЛЕДСТВИЯ, КАСАЮЩИЕСЯ ПРОБЛЕМ ПРОФИЛАКТИКИ

Сальваторе Джакомуцци

Доктор медицинских наук, доктор психологических наук, кафедра психиатрии и психотерапии, Вена, Австрия

Клаус Гарбер

Доцент, доктор, факультет психологии, Университет Зигмунда Фрейда, Вена, Австрия

М. Эртл

Кафедра психиатрии, Университет Инсбрука, Инсбрук, Австрия

Наталья Баринова

Харьковский национальный университет имени В.Н. Каразина, Харьков, Украина

Александр Кочарян

Харьковский национальный университет имени В.Н. Каразина, Харьков, Украина В статье представлен обзор проблем детского насилия, широкий спектр его вариантов - физического, сексуального и психологического насилия и т.п. Показано, что детское насилие обладает качеством трансгенерации, в той или иной форме воспроизводится в следующих поколениях. Опыт насилия также является негативным предиктором насильственного поведения, которое проявится в воспитании собственных детей. Представлены показатели эпидемиологии насилия. Данные очень колеблются, например, распространенность сексуального насилия колеблется от 3\% до 36\%. От сексуального насилия в основном страдают дети в возрасте от 6 до 13 лет. Дети в возрасте до 4 лет чаще всего страдают от физического и психологического насилия. До трети жертв сексуального насилия могут проявлять соответствующее поведение по отношению к своим или другим детям. Представлен обзор факторов, которые предиспонируют / ретардируют формирование детского насилия. Это такие факторы, как возраст, пол, этническое происхождение, наличие инвалидности и социальный статус родителей. Профилактическая работа должна основываться на многоуровневой концепции (участвуют несколько участников или учреждений). Соответствующие меры по предотвращению насилия не должны (не могут) быть направлены только на детей / молодых людей, но должны также затрагивать, в частности, родителей и школу.

КЛЮЧЕВЫЕ СЛОВА: сексуальное, физическое и психологическое насилие над детьми, эпидемиология и профилактика детского насилия. 